\title{
PEMANFAATAN LIMBAH LIDI SAWIT MENJADI PRODUK BERNILAI EKONOMIS
}

\author{
Raden Lestari Garnasih') \\ ${ }^{1)}$ Fakultas Ekonomi dan Bisnis Universitas Riau \\ E-mail : raden.lestari@lecturer.unri.ac.id
}

\begin{abstract}
ABSTRAK
Perkebunan kelapa sawit di provinsi riau memiliki wilayah yang sangat luas di indonesia. Hal ini membuat orang sangat bergantung pada penjualan buah sawit mereka yang diolah oleh pabrik menjadi crude palm oil, sehingga, ketika harga minyak sawit domestik dan internasional turun, ini tentunya akan berdampak pada pengurangan kerugian produsen terhadap petani. Oleh karena itu petani membutuhkan sumber pendapatan lain sebagai alternatif lain untuk mempertahankan kehidupan mereka. Selama buah sawit dipanen, batang kelapa sawit dibuang atau dibakar. Kondisi ini tentu sangat disayangkan, karena batang kelapa sawit dapat diolah menjadi produk bernilai ekonomi. Melalui kegiatan ini, masing-masing keluarga diharapkan dapat menghasilkan produk anyaman yang memiliki nilai ekonomi, kreatif dan inovatif, sehingga dapat meningkatkan kesejahteraan keluarga dan masyarakat. Masyarakat pertama-tama diberi pemahaman tentang maksud dan tujuan kegiatan, sehingga mereka memiliki konsep / pandangan yang sama. Kegiatan selanjutnya, melatih kader dan anggota pkk, dibimbing oleh pelatih yang berkualitas. Hasil pelatihan menunjukkan bahwa para ibu dapat menghasilkan lebih banyak, kualitas yang lebih baik, dan produk anyaman yang lebih cepat pada hari kedua pelatihan.
\end{abstract}

Kata Kunci : Pemberdayaan, Masyarakat, Ekonomis

\begin{abstract}
Oil palm plantations in Riau province have a very large area in Indonesia. his makes people very dependent on the sale of their palm fruit processed by the mill into Crude Palm Oil, so that, when domestic and international palm oil prices decline, this will certainly have an impact on reducing producers' losses to farmers. Therefore farmers need another source of income as another alternative to sustain their lives.

As long as the palm fruit is harvested, the palm oil stick is thrown away or burned. This condition is certainly very unfortunate, because palm oil sticks can be processed into products of economic value. Through this activity, each family is expected to be able to produce woven products that have economic, creative and innovative value, so as to improve the welfare of the family and the community. The public is first given an understanding of the aims and objectives of the activity, so that they have the same concept / outlook. The next activity, training cadres and PKK members, was guided by a qualified trainer. The results of the training show that mothers are able to produce more, better quality and faster woven products on the second day of training.
\end{abstract}

Key Words : Empowerment, Community, Economist 


\section{PENDAHULUAN}

Pembangunan daerah pedesaan saat ini menjadi perhatian penting pemerintah Indonesia, dan hal ini dapat dilihat dari dikeluarkannya perundang-undangan dan Peraturan Pemerintah yang merupakan dasar hukum pembentukan BUMDes di Indonesia yakni Undang-Undang Nomor 06 Tahun 2014, tentang Desa (Bab X Badah Usaha Milik Desa), Pasal 87, Pasal 88, Pasal 89, Pasal 90, yang kemudian diturunkan dalam bentuk Peraturan Pemerintah No. 43 Tahun 2014, tentang Peraturuan Pelaksanaan Undang Undang No. 06 Tahun 2014 Tentang Desa (Bab VIII Badan Usaha Milik Desa), Pasal 132 Sampai Pasal 142.

Salah satu kabupaten di Indonesia yang telah memiliki BUMDes adalah kabupaten Kuantan Singingi, dimana pendiriannya diidasarkan padaPeraturan Daerah No 10 Tahun 2010 tentang Pendirian Bumdes Di Kabupaten Kuantan Singingi, Peraturan Bupati Kuantan Singingi No 43 Tahun 2017 tentang Badan Usaha Milik Desa di Kabupaten Kuantan Singingi. Dari data yang diidentifikasi Bumdes, kabupaten Singingi memiliki delapan (8) jenis kategori produk unggulan yang terdiri dari usaha pertanian , perkebunan, perikanan , peternakan, hortikultura , pengolahan makanan , kerajinan tangan dan pertambangan .

Dari berbagai macam sektor komoditi uggulan tersebut, sektor perkebunan merupakan yang terbesar yang hampir melingkupi di seluruh wilayah kabupaten Kuantan Singingi, dengan luas area perkebunan kelapa sawit 130.486,98 ha, dimana Kecamatan Singingi merupakan daerah yang memiliki luas perkebunan 19.407, $01 \mathrm{Ha}$ (BPS, 2016). Kondisi ini menggambarkan bahwa kelapa sawit merupakan tumpuan hidup sebahagian besar masyarakat di kabupaten Kuantan Singingi, yang dapat diartikan juga, bahwa masyarakat Kuansing bergantung hidupnya pada sawit. Kondisi ini tentunya memiliki manfaat dan keuntungan bagi masyarakat, namun demikian perlu diingat bahwa komoditi kelapa sawit juga memiliki keterbatasan untuk selalu memberikan keuntungan bagi masyarakat, yakni ketika kelapa sawit tidak bisa dikembangkan lagi, mungkin harga yang bersaing, kemudian sawit juga bisa sewaktu-waktu anjlok harganya, sehingga perlu semacam "bumper" untuk memenuhi kehidupan masyarakat.Oleh sebab itu, perlu adanya pengembangan produk yang bersumber dari pohon kelapa sawit, bukan hanya menghasilkan minyak kelapa sawit (oil palm).

Luasnya area perkebunan kelapa sawit yang ada di desa Sei Sirih, Kecamatan Singingi, selama ini telah menghasilkan minyak kelapa sawit dalam jumlah besar, namun, limbah dari bahagian pohon kelapa sawit, belum dimanfaatkan menjadi produk yang unik dan bernilai ekonomis, yang diharapkan juga mampu membuka kesempatan kerja. Limbah lidi sawit, ternyata tidak hanya bisa diolah menjadi sapu atau tusuk sate saja, namun juga bisa disulap menjadi kerajinan menarik yang unik dan diminati konsumen di pasar domestik maupun internasinal. Tentunya dengan dukungan dari berbagai pihak, misalnya pemerintah daerah ataupun pihak-pihak yang turut bertanggung jawab pada peningkatakan kesejahteraan masyarakat, misalnya perguruan tinggi, sangat dibutuhkan. Bantuan ini sangat dibutuhkan mengingat para pemilik perkebunan ataupun para pengrajin limbah lidi sawit berdomisili di kawasan perkebungan yang jauh dari kawasan perkotaan dan masyarakat belum memiliki kemampuan dan keterampilan untuk menghasilkan produk yang lebih beragam.

Kerajinan tangan dalam bentuk anyaman nan unik membutuhkan ketekunan, kesabaran serta sentuhan kreativitas pengrajin. Dengan modal lidi kelapa sawit, vanish, dan pewrna limbah lidi kelapa sawit dapat diubah menjadi produk yang unik dan bernilai ekonomis, yakni aneka bentuk souvenir, seperti piring tempat buah, parcel, mangkok nasi, 
kotak pensil, kotak tisu, sandal, bahkan lampu hias yang sangat unik.Namun, untuk mencapai kepada kemampuan menghasilkan produk yang unik dan bernilai ekonomis, membutuhkan keterampilan dan sentuhan dari orangyang berpengalaman (profesional).Dengan demikian sangat tepatlah program pengabdian ini dilakukan untuk mencapai kehidupan masyarakat yang lebih bernilai dan sejahtera.

Kegiatan pengabdian ini bertujuan untuk memberdayakan masyarakat desa Sei Sirih, Kuansing melalui pembuatan/produksi produk unik bernilai ekonomis dan mampu membuka kesempatan kerja melalui kegiatan sebagai berikut :

1. Mensosialisasikan potensi limbah sawit (lidi sawit).

2. Menginventarisir masyarakat yang bersedia mengikuti program pemberdayaan melalui pemanfaatan lidi kelapa sawit.

3. Menginventarisir potensi pasar produk anyaman

4. Memproduksi produk anyaman.

5. Melakukan penyuluhan pemasaran produk anyaman.

6. Melakukan penyuluhan pembukuan produksi dan penjulan sederhana .

\section{TINJAUAN PUSTAKA.}

Pemberdayaan masyarakat adalah proses pembangunan di mana masyarakat berinisiatif untuk memulai proses kegiatan sosial untuk memperbaiki situasi dan kondisi diri sendiri. Pemberdayaan masyarakat hanya bisa terjadi apabila masyarakat ikut pula berpartisipasi.(hhttp://id.wikipedia.org/wiki/Pemberdayaan_masyarakat).

Pemberdayaan juga bermakna sebagai pemberi daya atau penguatan kepada masyarakat (Mardikanto, 2014).

Dilihat dari defenisi yang dikemukan tersebut di atas, dapat dilihat bahwa pemberdayaan yang dilakukan memiliki tujuan dan dilakukan dengan menggunakan proses, sebagaimana yang dijelaskan oleh Suharto (2005) yang mendefenisikan pemberdayaan sebagai upaya untuk memperkuat kelompok lemah di masyarakat termasuk individu-individu yang berada dalam kondisi miskin.

Sebagai tujuan, pemberdayaan menunjuk pda keadaan yang ingin dicapai oleh sebuah perubahan sosial, yaitu masyarakat yang berdaya, memiliki kekuasan atau pengetahuan dan kemampuan dalam memenuhi kebutuhan hidupnya baik bersifat fisik, ekonomi maupun sosial seperti kepercayaan diri, menyampaikan aspirasi, mempunyai mata pencaharian, berpartisipasi dalam kegiatan sosial, dan mandiri dalam melaksnakan tugas-tugas kehidupannya.

Usaha atau upaya yang dilakukan dalam memberdayakan masyarakat dapat dilakukan melalui enabling, empowerment, dan protecting (Fahrudin, 2012), yang dijelaskan sebagai berikut :

1. Enabling yakni menciptakan suasana atau iklim yang memungkinkan potensi masyarakat berkembang. Titik tolaknya adalah bahwa setiap manusia, setiap masyarakat memiliki potensi yang dapat dikembangkan. Pemberdayaan adalah upaya untuk membangun daya itu dengan cara mendorong (encourage), memotivasi, dan membangkitkan kesadaran (awareness) akan potensi yang dimilikinya serta berupaya untuk mengembangkannya.

2. Empowering, yaitu meningkatkan kapaspitas dengan memperkuat potensi atau daya yang dimiliki oleh masyarakat. Perkuatan ini meliputi langkah-langkah nyata seperti penyediaan berbagai masukan (input) serta pembukaan akses kepada berbagai peluang yang dapat membuat masyarakat menjadi makin berdayaan. 
3. Protecting, yaitu melindungi kepentingan dengan mengembangkan sistem perlindungan bagi masyarakat yang menjadi subjek pengembangan. Dalam proses pemberdayaan harus dicegah yang lemah menjadi bertambah lemah, oleh karena kekurangberdayaan dalam menghadapi yang kuat. Melindungi dalam hal ini dilihat sebagai upaya untuk mencegah terjadinya persaingan yang tidak seimbang serta eksploitasi yang kuat atas yang lemah.

\section{Tujuan Pemberdayaan}

Tujuan pemberdayaan dalam masyarakat, antara lain adalah untuk pembentukan pemberdayaan masyarakat melalui potensi yang ada, memperkuat potensi tesebut, dan membentengi masyarakat dari berbagai ketertindasan dalam aspek ekonomi. Selain itu tujuan pemberdayaan adalah perbaikan-perbaikan (Mardikanto, 2014) pada kelembagaan (better institution), usaha (better business), lingkungan (better environment), kehidupan (better living) dan masyarakat (better community).

Prinsip Pemberdayaan

Prinsip kesetaraan, partisipasi, keswadayaan atau kemandirian, serta berkelanjutan digunakan untuk mensukseskan program pemberdayaan (Najiati, 2005), yang dapat dideskripsikan sebagai berikut :

1. Prinsip Kesetaraan.

Prinsip utama yang harus dipegang dalam proses pemberdayan adalah adanya kesetaraan atau kesejajaran kedudukan antara masyarakat dengan lembagayang melakukan program-program kesetaraan.

2. Partisipasi

Program pemberdayaan yang dapat menstimulasi kemandirian masyarakat adalah program yang sifatnya partisipatif, direncanakan, dilaksanakan, diawasi, dan dievaluasi oleh masyarakat. Namun, untuk sampai pada tingkat tersebut perlu waktu dan proses pendampingan yang melibatkan pendamping yang berkomitmen tinggi terhadap pemberdayaan masyarakat.

1. Kesetaraan atau Kemandirian.

Prinsip ini mengedepankan kemampuan masyarakat daripada bantuan pihak lain. Konsep ini tidak memandang orang miskin sebagai objek yang tidak berkemampuan (the have not), melainkan sebagai subjek yang memiliki kemampuan sedikit (the have little). Mereka memiliki kemampuan unutk menabung, pengetahuan yang mendalam tentang kendala-kendala usahanya, megetahui kondisi lingkungannya, memiliki tenaga kerja dan kemauan, serta memiliki norma-norma bermasyarakat yang sudah lama dipatuhi. Semua itu harus digali dan dijadikan modal dasar bagi proses pemberdayaan. Bantuan dari orang lain yang bersifat materiil harus dipandang sebagai penunjang, sehingga pemberian bantuan tidak justru melemahkan tingkat keswadayaannya.

2. Berkelanjutan

Program pemberdayaan perlu dirancang untuk berkelanjutan, sekalipun pada awalnya peran pendamping lebih dominan dibanding masyarakat sendiri. Tapi secara perlahan dan pasti, peran pendamping akan makin berkurang, bahkan akhirnya dihapus, karena masyarakat sudah mampu mngelola kegiatannya sendiri. 
Strategi Pemberdayaan Masyarakat

a. Strategi tradisional. Strategi ini menyarankan agar masyarakat mengetahui dan memilih kepentingan terbaik secara bebas dalam berbagai keadaan. Dengan kata lain semua pihak bebas menentukan kepentingan bagi kehidupan mereka sendiri dan tidak ada pihak lain yang mengganggu kebebasan setiap pihak.

b. Strategi direct-action. Strategi ini membutuhkan dominasi kepentingan yang dihormati oleh semua pihak yang terlibat, dipandang dari sudut perubahan yang mungkin terjadi. Pada strategi ini, ada pihak yang sangat berpengaruh dalam membuat keputusan.

c. Strategi transformatif. Strategi ini menunjukkan bahwa pendidikan massa dalam jangka panjang dibutuhkan sebelum pengindentifikasian kepentingan diri sendiri.

Tahapan Pemberdayaan Masyarakat

Menurut Soekanto (1987), tujuh tahapan yang harus dilakukan :

1. Tahap Persiapan. Pada tahapan ini ada dua tahapan yang harus dikerjakan, yaitu: pertama, penyimpanan petugas, yaitu tenaga pemberdayaan masyarakat yang bisa dilakukan oleh community woker, dan kedua penyiapan lapangan yang pada dasarnya diusahakan dilakukan secara non-direktif.

2. Tahapan pengkajian (assessment). Pada tahapan ini yaitu proses pengkajian dapat dilakukan secara individual melalui kelompok-kelompok dalam masyarakat. Dalam hal ini petugas/tim pengabdian mengidentifikasi masalah kebutuhan yang dirasakan (feel needs) dan juga sumber daya yang dimiliki klien.

3. Tahap perencanaan alternatif program atau kegiatan. Pada tahapan ini peneliti sebagai agen perubahan (exchange agent) secara partisipatif mencoba melibatkan warga untuk berfikir tentang masalah yang mereka hadapi dan bagaimana cara mengatasinya. Dalam konteks ini masyarakat diharapkan dapat memikirkan beberapa alternatif program dan kegiatan yang dapat dilakukan.

4. Tahap pemfomalisasi rencana aksi. Pada tahapan ini agen perubahan membantu masing-masing kelompok untuk merumuskan dan menentukan program dan kegiatan apa yang mereka akan lakukan untuk mengatasi permasalahan yang ada. Di samping itu juga peneliti membantu untuk memformalisasikan gagasan mereka ke dalam bentuk tertulis, terutama bila ada kaitannya dengan pembuatan proposal kepada penyandang dana.

5. Tahap pelaksanaan (implementasi) program atau kegiatan. Dalam upaya pelaksanaan program pemberdayaan masyarakat peran masyarakat sebagai kader diharapkan dapat menjaga keberlangsungan program yang telah dikembangkan. Kerja sama antar petugas dan masyarakat merupakan hal penting dalam tahapan ini karena terkadang sesuatu yang sudah direncanakan dengan baik melenceng saat di lapangan.

6. Tahap evaluasi. Evaluasi sebagai proses pengawasan dari warga dan petugas program pemberdayaan masyarakat yang sedang berjalan sebaiknya dilakukan dengan melibatkan warga. Dengan keterlibatan warga tersebut diharapkan dalam jangka waktu pendek biasanya membentuk suatu sistem komunitas untuk pengawasan secara internal dan untuk jangka panjang dapat membangun komunikasi masyarakat yang lebih mendirikan dengan memanfaatkan sumber daya yang ada. 
7. Tahap terminasi. Tahap terminasi merupakan tahapan pemutusan hubungan secara formal dengan komunitas sasaran. Dalam tahap ini diharapkan proyek harus segera berhenti.

\section{METODE PELAKSANAAN}

Kegiatan pengabdian ini dilakukan dengan beberapa tahapan :

1. Memotret potensi desa

2. Melalui diskusi dengan pemuka desa (kades, manajeman Bumdes, serta ibu-ibu PKK), diputuskan bahwa pelatihan yang akan diberikan adalah pelatihan pembuatan produk anyaman.

3. Diputuskan pula bahwa pelatihan akan sangat baik diberikan kepada ibu-ibu kader dan anggota PKK.

4. Pensosialisasian kegitan.

5. Pelatihan selama dua hari.

6. Kompetisi pembuatan anyaman

7. Pembuatan kelompok produksi

8. Pelatihan manajemen dan motivasi bisnis. (manajemen pemasaran, pembukuan sederhana).

\section{HASIL DAN PEMBAHASAN}

Pentrasferan ilmu pengetahuan, teknologi dan seni yang dilakukan melalui kegiatan desa binaan ini dapat memberikan peningkatan wawasan, cara berpikir, nilainilai dan perubahan perilaku kea rah yag lebih baik. Kegitan dilakukan melalui penanaman pemahaman kepada masyarakat bahwa institusi penidikan, dalam hal ini Universitas Riau memiliki kewajiban untuk memperbaiki taraf kesejahteraan masyarakat melalui perubahan pola pikir dan perilaku.

Melalui diskusi dengan aparat desa, Bumdes dan ibu-ibu PKK Sei Sirih, mereka memiliki harapan yang besar kepada tim pengabdian, bahwa apa yang dihasilkan dari program ini akan mampu memberi peningkatan penghasilan bagi masyarakat. Ini menunjukkan bahwa masyarakat mendukung setiap kegiatan yang dilaksanakan.

Pensosialisasian kegitan kepada ibu-ibu kader dan anggota PKK, diberikan untuk menciptakan pemahaman dan membuka pikiran peserta, bahwa lidi sawit yang selama ini dibuang dan dibakar begitu saja, ternyata memiliki nilai ekonomis, jika diolah menjadi produk-produk yang kreatif dan inovatif. Adanya pemahaman peserta, dapat diindikasikan dari antusias mereka yang mendaftar pada kegiatan-kegiatan berikutnya.

Pelatihan di hari pertama, dihadiri oleh ibu-ibu dari strata usia yang berbeda-beda, ada yang muda dan bahkan yang tua. Peserta sedikit mengalami kesulitan dalam menganyam lidi sawit. Hal ini terjadi karena belum terbiasa, lidi sawit yang sering patah, karena terlalu kuat menarik, dan kualitas lidi sawit yang kurang bagus untuk dianyam.

Melalui pelatihan ini pula dapat dilihat bahwa antara satu peserta dengan peserta lainya sangat peduli untuk membantu teman yang belum bisa. Perilaku tolong menolong sangat kental dirasakan pada pelatihan ini. Saling memotivasi antar peserta juga sangat terasa. Kerjasama, dan antusias ditunjukkan oleh setiap peserta. 


\section{KESIMPULAN}

Dari kegitan ini , maka dapat disimpulkan beberapa point, yakni:

1. Peserta pelatihan mampu menghasilkan produk anyaman lebih cepat, berkualiatas dan banyak di hari kedua pelatihan.

2. Peserta memiliki pendapat yang sama bahwa pelatihan yang diberikan menambah keterampilan baru yang nantinya akan dikembangkan menjadi produk yang dapat dibisniskan.

Adapun saran-saran untuk masa yang akan datang adalah:

1. Melakukan penyebaran keterampilan pembuatan anyaman di desa-desa lainnya, yang dilakukan oleh ibu-ibu desa Sei Sirih yang sudah terampil menghasilkan produk anyaman .

2. Bekerja sama dengan pemerintah tingkat kecamatan, sehingga pentransferan keterampilan akan lebih mudah diwujudkan.

3. Bekerjasama dengan pihak terkait membangun desa-desa penghasil produk anyaman dengan ciri khas daerah kuantan singing.

\section{DAFTAR PUSTAKA}

[1]. Badan Pusat Statistik Kuantan Singingi, 2016

[2]. Fahrudin, Adi. 2012. Pemberdayaan, Partisipasi dan Penguatan Kapasitas Masyarakat, Bandung, Humaniora

[3]. Gorham, Daniels, Elizabeth; Daniels, Michelle, Ann; Enelvoldsen, L, Bernadine. (2005). Empowering Rural Families to Create Secure Communities. Journal of Family and Consumer Sciences. 97, 1: career \& Technical Education Data Base.

[4]. Hikmat, Harry. 2006. Strategi Pemberdayaan Masyarakat. Bandung. Humaniora

[5]. Mardikanto, Totok. 2014. CSR (corporate Social Responsibility) (Tanggung Jawab Sosial Korporasi). Bandung; Alfabeta

[6]. Najiati, Sri. 2005. Pemberdayaan masyarakat di Lahan Gambut. Bogor: Wetlands Interational.

[7]. Suharto, Edi. 2005. Membangun Masyarakat Memberdayakan masyarakat. Bandung: Refika Aditama 